\title{
Tear meniscometry test in wild animals
}

\author{
Arianne Pontes Oriá ${ }^{*}$ (D) Ana Cláudia Santos Raposo ${ }^{1}$ Vinícius José da Silva Cardoso de Brito ${ }^{1}$ \\ Nayone Lima Lantyer Cordeiro de Araújo ${ }^{1}$ Maria Madalena Souza Oliveira ${ }^{1}$ \\ Isaac Manoel Barros Albuquerque ${ }^{2}$
}

${ }^{1}$ Departamento de Anatomia, Patologia e Clínicas Veterinárias Universidade Federal da Bahia (UFBA), 40170110, Bahia, BA, Brasil. ${ }^{2}$ Mister Cayman LTDA, 57070400, Maceió, AL, Brasil. E-mail: arianneoria@ufba.br. "Corresponding author.

ABSTRACT: This study aimed to describe strip meniscometry test values for Amazona aestiva (turquoise-fronted amazon), Ara ararauna (blue-and-yellow macaw) and Caiman latirostris (broad-snouted caiman). Twenty-one Amazona aestiva and 11 Ara ararauna, healthy, adults of unknown sex, and 37 healthy adult Caiman latirostris (27 males and 10 females), were used in this investigation. All animals were manually restrained and I-Tear ${ }^{\circledR}$ Test strip was inserted for 5 at the edge of the lower tear meniscus, without touching the eyelid or ocular surface, immediately followed by measurement (millimeter per 5 seconds). No differences were reported between left and right eyes for Amazona aestiva $(P=0.824)$, Ara ararauna $(P=0.262)$ and Caiman latirostris $(P=0.679)$. Median and confidence interval were 2.0 (2.25-3.56) $\mathrm{mm} / 5 \mathrm{~s}$ for Amazona aestiva, 3.0 (2.93-4.15) $\mathrm{mm} / 5 \mathrm{~s}$ for Ara ararauna and $3.0(2.55-4.90) \mathrm{mm} / 5 \mathrm{~s}$ for Caiman latirostris. These values for strip meniscometry tear test can be used as parameters for each species and may be helpful for diagnosis and treatment of tear-production disorders in birds and reptiles.

Key words: bird, strip meniscometry tube, reptile, tear meniscus, tear production.

Teste de meniscometria lacrimal em animais silvestres

RESUMO: O objetivo deste estudo foi descrever os valores do teste de meniscometria lacrimal para Amazona aestiva (papagaio-verdadeiro), Ara ararauna (arara-canindé) e Caiman latirostris (jacaré-de-papo-amarelo). Vinte e um Amazona aestiva, 11 Ara ararauna adultos, de sexo desconhecido, e 37 Caiman latirostris adultos (27 machos e 10 fêmeas), foram utilizados nesta investigação. Todos os animais foram contidos manualmente e uma tira do I-Tear ${ }^{\circledR}$ test foi inserida por 5 segundos na borda do menisco inferior, sem tocar a pálpebra ou a superficie ocular, e imediatamente mensurada (milimetro por 5 segundos). Não foram encontradas diferenças entre os olhos esquerdos e direitos para Amazona aestiva $(P=0,824)$, Ara ararauna $(P=0,262)$ e Caiman latirostris $(P=0,679)$. Mediana e intervalo de confiança foram de $2,0(2,25-3,56)$ $\mathrm{mm} / 5 \mathrm{~s}$ para Amazona aestiva, 3,0 (2,93-4,15) $\mathrm{mm} / 5 \mathrm{~s}$ para Ara ararauna e 3,0 $(2,55-4,90) \mathrm{mm} / 5 \mathrm{~s}$ para Caiman latirostris. Estes valores para o teste de meniscometria podem ser utilizados como parâmetros para estas espécies e podem ser úteis para diagnosticar e tratar distúrbios de produção lacrimal em aves e répteis.

Palavras-chave: ave, meniscometria, menisco lacrimal, produção de lágrima, réptil.

\section{INTRODUCTION}

The corneal and scleral surface are covered by the tear film which possess a protective function and nutritional properties for maintenance of ocular health (ROLANDO \& ZIERHUT, 2001). The eyelid blinking spreads the tear fluid over the ocular surface, inferior and superior meniscus, and conjunctival sac (TIFFANY, 2008). Thus, changes in tear turnover or production may result in changes in distribution and induce ophthalmopathies (ROLANDO \& ZIERHUT, 2001). Establishment of lacrimal production values is an important tool for routine semiotechnique, and for wild animals Schirmer tear test (STT), endodontic absorbent paper point tear test (EAPPTT) and phenol red thread tear test (PRTT) can be used (ORIÁ et al., 2013a, 2013b; MONÇÃO-SILVA et al., 2016a, 2016b; FALCÃO et al., 2017a, 2017b). These evaluations are similar once the test strips are inserted in the conjunctival sac, for basal and reflex tear quantification, without anesthetic eye drops (TROST et al., 2007). However, studies estimate that the region of tear meniscus may contain up to $90 \%$ of the total volume of tear fluid in humans (SHEN et al., 
2008), and because of this, tear meniscometry test may complement tear production evaluation in wild animals. Different methods of tear meniscus quantification have been reported for humans, including evaluations using optical coherence tomography, but high cost limits their use (SHINZAWA et al., 2018).

The strip meniscometry tube (SMT) evaluates the tear volume present in the palpebral meniscus rapidly and non-invasively (DOGRU et al., 2006; IBRAHIM et al., 2011; KAZAMA et al., 2014; RAJAEI et al., 2017) and these technical features are important for wild animals, once the physically restraining time must be fast (MARCO et al., 2006). The use of SMTs has been reported for some domestic species, such as dogs, cats and rabbits (KAZAMA et al., 2014; RAJAEI et al., 2017; MIYASAKA et al., 2019), and studies in non-domestic species are described only in monkeys (RAPOSO et al., 2018).

The present study aimed to evaluate and establish reference parameters for SMT tests in Amazona aestiva (turquoise-fronted amazon), Ara ararauna (blue-and-yellow macaw) and Caiman latirostris (broad-snouted caiman), as an ophthalmic semi-technical instrument for measuring lacrimal production in wild animals.

\section{MATERIALS AND METHODS}

Animals

Twenty-one Amazona aestiva (turquoisefronted amazon) and 11 Ara ararauna (blue-and- yellow macaw) adults, of unknown sex, obtained from the Triage Center of Wild Animals (Salvador, Bahia, Brazil); and 37 adult Caiman latirostris (27 males and 10 females) obtained from a commercial establishment (Mister Cayman LTDA, Maceió, Alagoas, Brazil), were used in this investigation. All animals were manually restrained and the evaluations were performed in the morning hours, with average temperature and humidity of $24.61{ }^{\circ} \mathrm{C}$ and $59.3 \%$, respectively.

Physical and ophthalmic examinations were performed by the technical staff and veterinary ophthalmologist (UFBA). All animals were subjected after SMT, to inspection of the eye and periocular region in normal light for gross abnormalities with a binocular magnifying loupe $3 \mathrm{X}$ and a transilluminator. Routine ophthalmic tests, such as fluorescein were also conducted to ensure the health of the eye. Animals that presented any clinical signs of systemic disease or gross abnormalities of the eye or periocular region were excluded.

\section{Meniscometry tear test}

One I-Tear ${ }^{\circledR}$ Test strip (Imed, Dollard-desOrmeaux, Canada) was carefully inserted in each eye, slightly off-center temporally, for 5 seconds at the edge of the lower tear meniscus, without touching the eyelid or the ocular surface (Figure 1), and then immediately measured, without the use of topical anesthesia, as described by Miyasaka et al. (2019). The eyelid position remained neutral with no manual

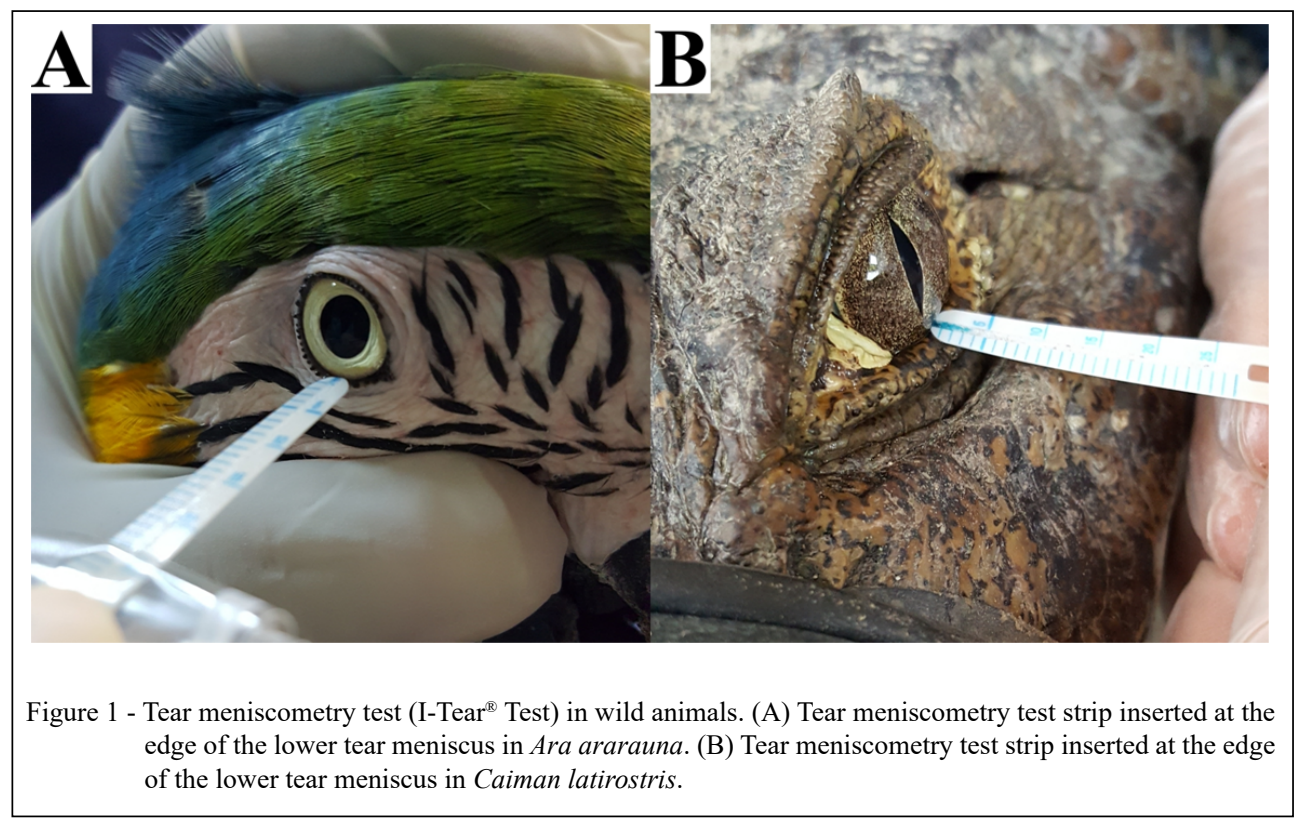

Ciência Rural, v.49, n.11, 2019. 
eversion. The duration of the test was timed with a stopwatch. Length of the blue stained tear column in the central membrane ditch (in millimeters) was considered as the meniscometry strip value for that eye in $\mathrm{mm} / 5 \mathrm{~s}$.

\section{Statistical analysis}

Shapiro-Wilk test was used to assess the normality of the SMT values. Wilcoxon test for paired groups was used to compare results between left and right eyes. For analysis, the SPSS program (version 22.0) was used and the level of significance was set to $5 \%$.

\section{RESULTS AND DISCUSSION}

Evaluation of tear volume is considered important for the diagnosis of diseases such as dry eye (IBRAHIM et al., 2010, 2011; KAZAMA et al., 2014; RAJAEI et al., 2017; RAPOSO et al., 2018; NICHOLS et al., 2004; MARCO et al., 2006). However, invasive methodologies may induce ocular irritation, discomfort or reflex lacrimation (TIFFANY, 2008; IBRAHIM et al., 2010). The SMT has been shown effective for measuring tear production, with the use of a single strip for both eyes and it can serve as an alternative method for evaluating tear production (IBRAHIM et al., 2011; RAJAEI et al., 2017; RAPOSO et al., 2018).

The data were not normally distributed according to Shapiro-Wilk test. There were no significant differences between the left and right eyes for Amazona aestiva $(P=0.824)$, Ara ararauna $(P=0.262)$ and Caiman latirostris $(P=0.679)$. Results are shown in table 1.

The test was more difficult to execute with birds due to the nictitating membrane reflex when the strip approached the inferior eyelid. Sometimes, during the test (strip inserted at the edge of the lower tear meniscus), incursion of the nictitating membrane removed the strip from the site and a rapid increase in

Table 1 - Median and confidence interval (CI) for strip meniscometry tube (SMT) test in Amazona aestiva, Ara ararauna and Caiman latirostris.

\begin{tabular}{lcc}
\hline Species & SMT $(\mathrm{mm} / 5 \mathrm{~s})$ & $95 \% \mathrm{CI}$ \\
\hline Amazona aestiva & 2.0 & $2.25-3.56$ \\
Ara ararauna & 3.0 & $2.93-4.15$ \\
Caiman latirostris & 3.0 & $2.55-4.90$ \\
\hline
\end{tabular}

tear production was observed. As these changes were not foreseen and could not be avoided, the obtained data were retained in the final result. These behaviors were not observed for Caiman latirostris. Difficulties in the evaluation of tear production in noncollaborative animals are described in other studies, as the use of PRT in birds, also due to incursion of the nictitating membrane (BECKWITH-COHEN et al., 2015; BLISS et al., 2015; MONÇÃO-SILVA et al., 2016b). Faster filling of the strip capillary might have been caused by tearing during eyelid incursion, which may be attributed to a renewal in the tear reservoir present in the meniscus (UCHIDA et al., 2007).

The animals constantly moved their heads during the investigation, which made it difficult to perform the test; although, the manipulators had undergone prior training as suggested by IBRAHIM et al. (2011). RAJAEI et al. (2007) also reported agitation in rabbits and cats during the test, possibly induced by the strip approaching of the animal's eye.

The median values reported for Amazona aestiva, Ara ararauna and Caiman latirostris for SMT were lower than the averages reported for dogs 9.78 $\pm 3.68 \mathrm{~mm} / 5 \mathrm{~s}$ and $9.66 \pm 2.15 \mathrm{~mm} / 5 \mathrm{~s}($ KAZAMA et al., 2014; RAJAEI et al., 2017), cats $10.50 \pm 0.7$ $\mathrm{mm} / 5 \mathrm{~s}$ (RAJAEI et al., 2017), rabbits $4.72 \pm 1.20$ $\mathrm{mm} / 5 \mathrm{~s}$ (RAJAEI et al., 2017) and capuchin monkeys (Sapajus sp.) $8.0 \pm 1.625 \mathrm{~mm} / 5 \mathrm{~s}$ (RAPOSO et al., 2018). However, the STT evaluations of tear production for domestic species (RAJAEI et al., 2017) and capuchin monkeys (ORIÁ et al., 2013b; MONTIANI-FERREIRA et al., 2008) are also higher than those reported for the species in the present study (ORIÁ et al., 2013a; FALCÃO et al., 2017a, 2017b). A statistical correlation between positive STT and tear meniscometry test for humans (DOGRU et al., 2006; IBRAHIM et al., 2010) and dogs (KAZAMA et al., 2014; RAJAEI et al. 2017; MIYASAKA et al., 2019) has been reported, so it is suggested that the values reported in our study are consistent with those expected for the evaluated species.

In the present study, the obtained median values were lower than other tear production tests placed in the conjunctival sac, including PRT (12.6 \pm $2.6 \mathrm{~mm} / 15 \mathrm{~s}$ and $19.12 \pm 3.14 \mathrm{~mm} / 15 \mathrm{~s}$ ) and EAPPTT $(13.1 \pm 1.4 \mathrm{~mm} / \mathrm{min}$ and $16.74 \pm 1.38 \mathrm{~mm} / \mathrm{min})$ for Amazona aestiva and Ara ararauna respectively (MONÇÃO-SILVA et al., 2016a, 2016b). Results for all tests (PRT, EAPPTT and SMT) were always lower for Amazona aestiva than Ara ararauna as well.

Tear production values reported for Caiman latirostris were lower than those observed for EAPPTT $(17.1 \pm 2.5 \mathrm{~mm} / \mathrm{min})$, but are close 
to those reported for STT (mean $3.4 \pm 3.6 \mathrm{~mm} /$ min and CI 2.01-4.78 $\mathrm{mm} / \mathrm{min}$ ) (ORIÁ et al., 2013a). Differences in the results among tests can be correlated with factors such as methodology employed or absorption properties of each material (ORIÁ et al., 2013a; BECKWITH-COHEN et al., 2015; SMITH et al., 2015; MONÇÃO- SILVA et al., 2016a; MONÇÃO-SILVA et al., 2016b; OLIVEIRA et al., 2017), as well as the anatomic and physiologic variability of each species (BECKWITH-COHEN et al., 2015; OLIVEIRA et al., 2017).

Despite the similar median results of SMT for Caiman latirostris and Ara ararauna, there are distinct anatomic characteristics, including palpebral fissure length, eye blink frequency, lacrimal gland and drainage system features that must be considered (ORIÁ et al., 2013; BECKWITH-COHEN et al., 2015; FALCÃO et al, 2017a; MONÇÃO-SILVA et al, 2016b; OLIVEIRA et al., 2017). However, there are no corneal surface abnormalities in the studied animals, supporting the hypothesis of a stable tear film (LAWTON, 2005; DELGADO et al., 2014; ORIÁ et al., 2013a) that is adapted to the environment of each population; and studies demonstrated factors, such as composition and disposition of the tear film aiding the understand of homeostasis dynamic maintenance in the ocular surface for these species.

The SMT may be useful in the diagnosis of changes in lacrimal production (DOGRU et al., 2006; RAJAEI et al., 2017; MIYASAKA et al., 2019) and has been proven feasible for wild animals in particular, due to the fast manipulation and minimal discomfort of the subjects. Moreover, these results can provide information on tear dynamics once a relationship is established between tear meniscometry value and total tear volume (HOLLY, 1985; IBRAHIM et al., 2010).

\section{CONCLUSION}

The establishment of species-specific values can help in the diagnosis of ocular diseases and, when supplemented by other tests, may provide an understanding of the distribution of this important fluid across the ocular surface. Limitations encountered may be reduced by prior acquisition of manipulation skills and possible animal conditioning. SMT is shown to be a promising and feasible method in the ophthalmology of wild animals.

\section{ACKNOWLEDGEMENTS}

The authors are grateful to Triage Center for Wild Animals, Salvador-BA and Mister Cayman LTDA, Maceió-AL, from Brazil, for providing the birds and broad-snouted caiman. APO received strips for the clinical evaluations under-taken in this study and did not receive any grants, funding, or honorarium for the conduct of this research. This study was financed in part by the Coordenação de Aperfeiçoamento de Pessoal de Nível Superior - Brasil (CAPES) - Finance Code 001. APO is a research fellow from the National Council for Scientific and Technological Development (CNPq). ACSR ( $\left.{ }^{\circ} 88881.131559 / 2016-01\right)$, VJSCB $\left(\mathrm{n}^{\circ} 88882.453698 / 2019-01\right)$, NLLCA (nº8882.453705/2019-01) are a $\mathrm{PhD}$ fellow from CAPES and MMO is a $\mathrm{PhD}$ fellow from Fundação de Amparo à Pesquisa do Estado da Bahia - Brasil (FAPESB) - Finance Code: BOL0439/2018.

\section{BIOETHICS AND BIOSSECURITY COMMITTEE APPROVAL}

This study was approved by the Biodiversity Authorization and Information System, Brazilian Ministry of the Environment and the Ethics Committee on Animal Experimentation of the School of Veterinary Medicine and Zootechnology of UFBA (n. 72.2016). It was conducted in accordance with the Association for Research in Vision and Ophthalmology (ARVO) Statement for the Use of Animals in Ophthalmic and Vision Research.

\section{DECLARATION OF CONFLICT OF INTERESTS}

The authors declare no conflict of interest. The founding sponsors had no role in the design of the study; in the collection, analyses, or interpretation of data; in the writing of the manuscript, and in the decision to publish the results.

\section{AUTHORS' CONTRIBUTIONS}

The authors contributed equally to the manuscript.

\section{REFERENCES}

BECKWITH-COHEN, B.; et al. Differences in ocular parameters between diurnal and nocturnal raptors. Veterinary Ophthalmology, Oxford, v.18,p.98-105, 2015. Available from: $<$ https://doi.org/10.1111/ vop.12126>. Accessed: Apr. 09, 2019. doi: 10.1111/vop.12126.

BLISS, C. D.; et al. Ocular findings and reference values for selected ophthalmic diagnostic tests in the macaroni penguin (Eudyptes chrysolophus) and southern rockhopper penguin (Eudyptes chrysocome). Veterinary Ophthalmology, Oxford, v.18, p.86-93, 2015. Available from: < https://doi.org/10.1111/ vop.12123>. Accessed: Apr. 09, 2019. doi: 10.1111/vop.12123.

DOGRU, M.; et al. Strip meniscometry: a new and simple method of tear meniscus evaluation. Investigative Ophthalmology \& Visual Science, v.47, n.5, p.1895-1901, 2006. Available from: $<$ http://dx.doi.org/10.1167/ iovs.05-0802>. Accessed: Aug. 15, 2018. doi: 10.1167/iovs.05-0802.

FALCÃO, M.S.A.; et al. Reference values for selected ophthalmic tests of the blue-and-yellow macaw (Ara ararauna). Pesquisa Veterinária Brasileira, v.37, n.4, p.389-394, 2017a. Available from: $\quad<$ http://dx.doi.org/10.1590/S0100-736X2017000400014>. Accessed: Sep. 07, 2018. doi: 10.1590/S0100-736X2017000400014.

FALCÃO, M.S.A.; et al. Modified Schirmer tear test and rebound tonometry in bluefronted Amazon parrot (Amazona 
aestiva). Pesquisa Veterinária Brasileira, v.37, n.8, p.871873, 2017b. Available from: <http://dx.doi.org/10.1590/S0100736X2017000800015>. Accessed: Sep. 07, 2018. doi: 10.1590/ S0100-736X2017000800015.

HOLLY, F.J. Physical chemistry of the normal and disordered tear film. Transactions of the Ophthalmological Societies of the United Kingdom, v.104, p.374-380, 1985. Available from: <https://www. researchgate.net/publication/19300209_Physical_chemistry_of_the normal_and_disordered_tear_film>. Accessed: Apr. 06, 2019.

IBRAHIM, O.M.; et al The application of Visante optical coherence tomography tear meniscus height measurement in the diagnosis of dry eye disease. Ophthalmology, v.117, p.1923-1929, 2010. Available from: $<$ http://dx.doi.org/10.1016/j.ophtha.2010.01.057>. Accessed: Aug. 23, 2018. doi: 10.1016/j.ophtha.2010.01.057.

IBRAHIM, O.M.; et al. The efficacy, sensitivity, and specificity of strip meniscometry in conjunction with tear function tests in the assessment of tear meniscus. Investigative Ophthalmology \& Visual Science, v.52, p.2194-2198, 2011. Available from: $<$ http:// dx.doi.org/10.1167/iovs.10-5986>. Accessed: Aug. 23, 2018. doi: 10.1167/iovs.10-5986.

KAZAMA, Y.; et al. A novel method of lacrimal function testing: strip meniscometry. The Globe - Newsletter of the International Society of Veterinary Ophthalmology, p.5-6, jul. 2014. Available from: $<$ http://isvo.info/wp-content/uploads/2014/12/Issue-Summer-2014. pdf $>$. Accessed: Apr. 06, 2019.

MARCO, I.; et al. Capture myopathy in little bustards after trapping and marking. Journal of Wildlife Diseases, v.42, n.4, p.889-891, 2006 Available from: <http://dx.doi.org/10.7589/0090-3558-42.4.889>. Accessed: Aug. 23, 2018. doi: 10.7589/0090-3558-42.4.889.

MIYASAKA, K.; et al. A novel strip meniscometry method for measuring aqueous tear volume in dogs: Clinical correlations with the Schirmer tear and phenol red thread tests. Veterinary Ophthalmology, p.1-8, 2019. Available from: <https://doi.org/10.1111/vop.12664>. Accessed: Apr. 09, 2019. doi: 10.1111/vop.12664.

MONÇÃO-SILVA, R.; et al. Ophthalmic diagnostic tests in parrots (Amazona amazônica) and (Amazona aestiva). Journal of Exotic Pet Medicine, v.25, n.3, p.186-193, 2016a. Available from: $<$ http://dx.doi.org/10.1053/j.jepm.2016.05.002>. Accessed: Aug. 23, 2018. doi: 10.1053/j.jepm.2016.05.002.

MONÇÃO-SILVA, R.M.; et al. Ophthalmic parameters of Blue-andyellow Macaws (Ara ararauna) and Lear's Macaws (Anodorhynchus leari). Avian Biology Research, v.9, n.4, p.240-249, 2016b. Available from: $\quad<$ http://dx.doi.org/10.3184/175815516X14725499175746>. Accessed: Aug. 23, 2018. doi: 10.3184/175815516X14725499175746.

MONTIANI-FERREIRA, F; et al. Reference values for selected ophthalmic diagnostic tests of the capuchin monkey (Cebus apella). Veterinary Ophthalmology, v.11, n.3, p.197-201, 2008. Available from: $<$ http://dx.doi.org/10.1111/j.1463-5224.2008.00620.x>. Accessed: Aug. 30, 2018. doi: 10.1111/j.1463-5224.2008.00620.x.

NICHOLS, K.K.; et al. The repeatability of clinical measurements of dry eye. Cornea, v.23, p.272-285, 2004. Available from: $<$ https://insights.ovid.com/pubmed?pmid $=15084861>$. Accessed: Apr. 06, 2019. doi: 10.1097/00003226-200404000-00010.

OLIVEIRA, M. M.; et al. Reference values for selected ophthalmic diagnostic tests in the Caatinga Parakeet (Eupsittula cactorum) and
Yellow-chevroned Parakeet (Brotogeris chiriri). Avian Biology Research, v.10, n.4, p.211-217, 2017. Available from: $<$ https://doi org/10.3184/175815617X14951979279286>. Accessed: Apr. 09, 2019. doi: $10.3184 / 175815617 X 14951979279286$.

ORIÁ, A.P.; et al. Ophthalmic diagnostic tests, orbital anatomy, and adnexal histology of the broad-snouted caiman (Caiman latirostris). Veterinary Ophthalmology, v.18, n.1, p.30-39, 2013a. Available from: <http://dx.doi.org/10.1111/vop.12115>. Accessed: Aug. 23, 2018. doi: 10.1111/vop.12115.

ORIÁ,A.P.; et al. Conjunctival flora, Schirmer's tear test, intraocular pressure, and conjunctival cytology in neotropical primates from Salvador, Brazil. Journal of Medicine Primatology, v.42, n.6, p.287-292, 2013b. Available from: <http://dx.doi.org/10.1111/ jmp.12059>. Accessed: Aug. 15, 2018. doi: 10.1111/jmp.12059.

RAJAEI, S.M.; et al. Strip meniscometry in dogs, cats, and rabbits. Veterinary Ophthalmology, v.21, n.2, p.210-213, 2017. Available from: <http://dx.doi.org/10.1111/vop.12486>. Accessed: Aug. 15, 2018. doi: 10.1111/vop.12486.

RAPOSO, A.C.; et al. Evaluation of lacrimal production, osmolarity, crystallization, proteomic profile, and biochemistry of capuchin monkeys' tear film. Journal of Medicine Primatology, 2018. Available from: <http://dx.doi.org/10.1111/jmp.12368>. Accessed: Aug. 15, 2018. doi: 10.1111/jmp.12368.

ROLANDO, M.; ZIERHUT, M. The ocular surface and tear film and their dysfunction in dry eye disease. Survey of Ophthalmology, v.45, n.2, p.S203-S210, 2001. Available from: <http://dx.doi. org/10.1016/S0039-6257(00)00203-4>. Accessed: Aug. 30, 2018. doi: 10.1016/S0039-6257(00)00203-4

SHEN, M; et al. Diurnal Variation of Upper and Lower Tear Menisci. American Journal of Ophthalmology, v.145, n.5, p.801- 806, 2008. Available from: <https://doi.org/10.1016/j.ajo.2007.12.024>. Accessed: Apr. 09, 2019. doi: 10.1016/j.ajo.2007.12.024.

SHINZAWA, M.; et al.Application ofCASIASS-1000 optical coherence tomography tear meniscus imaging in testing the efficacy of new strip meniscometry in dry eye diagnosis. Eye \& Contact Lens, 2018. Available from: <http://dx.doi.org/10.1097/ICL.0000000000000312>. Accessed: Aug. 17, 2018. doi: 10.1097/ICL.0000000000000312.

SMITH, S. P.; et al. Evaluation of the phenol red thread tear test in Falconiformes. Journal of Avian Medicine and Surgery, v.29, p.25-29, 2015. Available from: <https://doi.org/10.1647/2008050>. Accessed: Apr. 09, 2019. doi: 10.1647/2008-050.

TIFFANY, J.M. The normal tear film. Developments in Ophthalmology, v.41, p.1-20, 2008. Available from: <http:// dx.doi.org/10.1159/000131066>. Accessed: Aug. 17, 2018. doi: $10.1159 / 000131066$.

TROST, K.; et al. Schirmer tear test, phenol red thread tear test, eye blink frequency and corneal sensitivity in the guinea pig. Veterinary Ophthalmology, v.10, n.3, p.143-146, 2007. Available from: $<\mathrm{http} / / /$ dx.doi.org/10.1111/j.1463-5224.2007.00521.x>. Accessed: Sep. 07, 2018. doi: 10.1111/j.1463-5224.2007.00521.x.

UCHIDA, A.; et al. Noninvasive interference tear meniscometry in dry eye patients with Sjögren Syndrome. American Journal of Ophthalmology, v.144, n.2, p.232-237, 2007. Available from: $<$ http://dx.doi.org/10.1016/j.ajo.2007.04.006>. Accessed: Sep. 07, 2018. doi: 10.1016/j.ajo.2007.04.006. 